\title{
Mapping connectivity and conflict risk to identify safe corridors for the Persian leopard
}

\author{
Arash Ghoddousi (D) Benjamin Bleyhl • Clara Sichau • Delaram Ashayeri • \\ Peyman Moghadas • Pooriya Sepahvand • Amirhossein Kh Hamidi • \\ Mahmood Soofi • Tobias Kuemmerle
}

Received: 7 September 2019/Accepted: 17 June 2020/Published online: 25 June 2020

(C) The Author(s) 2020

\begin{abstract}
Context Many large carnivores depend on habitat patches outside protected areas, as well as safe corridors between them. However, corridor assessments typically ignore potential conflicts between carnivores and people, which can undermine corridor effectiveness and thus conservation success.

Objectives We identified safe dispersal corridors and conflict-prone movement bottlenecks for Persian leopard (Panthera pardus saxicolor) between protected areas in the Alborz Mountains, Iran, by mapping habitat, landscape permeability, and conflict risk. We then identified priority areas for conservation
\end{abstract}

Electronic supplementary material The online version of this article (https://doi.org/10.1007/s10980-020-01062-0) contains supplementary material, which is available to authorized users.

A. Ghoddousi $(\bowtie) \cdot$ B. Bleyhl · C. Sichau .

T. Kuemmerle

Geography Department, Humboldt-University Berlin,

Unter den Linden 6, 10099 Berlin, Germany

e-mail: arash.ghoddousi@hu-berlin.de

B. Bleyhl · T. Kuemmerle

Integrative Research Institute for Transformations in Human-Environment Systems (IRI THESys), Humboldt-

University Berlin, Berlin, Germany

D. Ashayeri · P. Moghadas · P. Sepahvand ·

A. Kh Hamidi

Freelance Researcher, Tehran, Iran interventions according to the intensities of different threats.

Methods We mapped land cover using Landsat satellite images, gathered data on leopard and prey distributions and livestock depredation events via interview surveys in 69 cells of $6 \times 6 \mathrm{~km}$ each. We then used occupancy modeling to identify habitat patches, used circuit theory modeling to analyze landscape permeability, and assessed human-leopard conflict risk using generalized linear models.

Results Leopard habitat use increased with prey availability and decreased with elevation. Prey distribution, in turn, was mostly negatively influenced by agricultural lands and distance from protected areas. Conflict risk (i.e., probability of leopard depredation on livestock) was high in landscapes where agriculture was widespread and historical forest loss high. Not

M. Soofi

J.F. Blumenbach Institute of Zoology \& Anthropology,

University of Goettingen, Göttingen, Germany

M. Soofi

School of Biological Sciences, University of Aberdeen, Aberdeen, UK 
accounting for conflicts overestimated connectivity among habitat patches substantially.

Conclusions Human-carnivore conflicts are an important constraint to connectivity and should be considered in corridor assessments. Our study shows how habitat analysis, connectivity assessment, and conflict risk mapping can be combined to guide conservation planning for identifying habitat networks and safe corridors for carnivores in human-dominated landscapes.

Keywords Alborz mountains · Connectivity · Human-wildlife conflict · Iran · Occupancy modeling · Panthera pardus

\section{Introduction}

Landscapes across the globe are increasingly humandominated (Tilman et al. 2017). This is particularly problematic for large carnivores, which are wideranging and require large tracts of suitable and wellconnected habitat (Crooks et al. 2011; Ripple et al. 2014). Across the globe, these species are currently disappearing over large extents of their historical range as a result of habitat loss and fragmentation, as well as high mortality in human-dominated landscapes (Di Marco et al. 2014; Wolf and Ripple 2017). This is worrisome given that large carnivores play key roles in ecosystems (Ripple et al. 2014). Many protected areas are not large enough to host viable carnivore populations, driving large carnivores to seek habitat and dispersal corridors in surrounding landscapes (Crooks et al. 2011; Di Minin et al. 2016). Therefore, conservation planning to protect large carnivores and the ecological functions they provide must look beyond protected areas and identify strategies so these species can persist in human-dominated landscapes (Sanderson et al. 2002; Goswami and Vasudev 2017).

A central approach in this regard is to maintain connectivity between protected areas and habitat patches, commonly through retaining and establishing corridors (Tischendorf and Fahrig 2000; KramerSchadt et al. 2011). Corridors are landscape features that connect two or more habitat patches (or populations) so that individuals are able to move between the two without encountering major barriers (Tischendorf and Fahrig 2000). Therefore, identifying effective corridors requires an understanding of the key factors limiting functional connectivity (Vasudev et al. 2015). Corridor identification typically focusses on landscape features only, such as roads, high elevation, or the inhospitable matrix surrounding habitat patches, which affect structural connectivity (Tischendorf and Fahrig 2000; Kramer-Schadt et al. 2011). However, ecological factors such as predation, competition, and prey availability (Cushman et al. 2010), as well as species' intrinsic characteristics, such as avoidance of unsafe landscapes (Ciuti et al. 2012; LaPoint et al. 2013; Gehr et al. 2017), affect behavioral responses of organisms to landscape structure and thus functional connectivity (Vasudev et al. 2015). Ignoring such ecological and behavioral constraints to dispersal might thus overestimate corridor functionality and undermine conservation efforts (Chetkiewicz et al. 2006; Scharf et al. 2018). Approaches that consider mortality risks when deriving corridors are, therefore, urgently needed.

For large carnivores, there are a number of reasons for human-caused mortality, including wildlife-vehicle collisions or poaching (Ripple et al. 2014). However, retaliatory killing in response to conflict with humans is an increasingly important mortality factor in human-dominated landscapes (Treves and Karanth 2003; Lennox et al. 2018). This conflict usually occurs in the form of livestock depredation (Chapron et al. 2014; van Eeden et al. 2018), which in turn may result in the persecution and killing of carnivores, and ultimately elevate extinction risk (Michalski et al. 2006; Jędrzejewski et al. 2017). The effects of human-carnivore conflict are more farreaching than directly increasing mortality though. For instance, large predators in landscapes where humanrelated mortality is high may change their space and resource use (Bleicher 2017; Gehr et al. 2017) and may no longer exert a top-down control in food webs (Dorresteijn et al. 2015; Atkins et al. 2019). Likewise, high conflict risk can act as a barrier to movement (Vasudev et al. 2015; Goswami and Vasudev 2017). Therefore, ignoring human-carnivore conflict risk when identifying corridors may result in funneling dispersing individuals into 'ecological traps', where mortality risk is high (Little et al. 2002; Northrup et al. 2012) and thus, overestimating the effectiveness of corridors for carnivore movement (Goswami and Vasudev 2017). Conservation and corridor planning 
should, therefore, consider human-wildlife conflicts (Cushman et al. 2018; Festa-Bianchet 2018).

We know of only a single study (Cushman et al. 2018) that considered conflict risk when assessing corridors for species of conservation concern. This is mainly because approaches for modeling predation risk (Hebblewhite et al. 2005) have only recently been adapted to estimating conflict risk in space (Miller 2015; Rostro-García et al. 2016). These approaches typically are based on correlating conflict occurrence or prevalence to a suite of spatial determinants (using e.g., ensemble modeling, generalized linear models, or logistic regression). Such models have great potential to provide insights into drivers of human-wildlife conflict, to predict conflict hotspots, and to understand which landscape features are associated with higher conflict than others (Miller 2015). All of this can provide worthwhile information for designing conservation strategies that mitigate conflict (Miller 2015) and could be incorporated in corridor planning (Goswami and Vasudev 2017). Cushman et al. (2018) predicted high conflict zones for lions (Panthera leo) from rapid declines in expected dispersal rates using cumulative kernel values from movement data. We advance this approach (Cushman et al. 2018) by using empirical data on livestock depredation events and by applying conflict risk modeling to identify conflict-prone areas in corridors that link habitat patches of large carnivores.

Our goal here was to identify safe dispersal corridors between habitat patches for the Persian leopard ( $P$. pardus saxicolor), a wide-ranging large carnivore that critically depends on areas outside protected areas (Kiabi et al. 2002). We focused on the area between Golestan National Park and Jahan Nama Protected Area in the eastern Alborz Mountains, Iran, where no protected areas exist, but leopard occurrence has been reported (Kiabi et al. 2002). The area is also among the most fertile agricultural regions in notoriously drought-prone Iran, resulting in a humandominated landscape and a high potential for further land-use changes and habitat fragmentation (Ghoddousi et al. 2017). Moreover, leopards are responsible for frequent livestock depredation in the area (Ghoddousi et al. 2016), causing widespread conflict and retaliatory killings by local people. This likely affects the survival of the leopard population in this region in major ways, which is highly problematic because the entire, critically endangered Caucasus population of
Persian leopard strongly depends on immigrations from Iran (Askerov et al. 2015). Assessing where both permeable and safe corridors are found will thus contribute to leopard conservation beyond the study region, in the entire Caucasus-Hyrcanian Biodiversity Hotspot. Specifically, our objectives were (1) to identify habitat patches from estimated leopard habitat use; (2) to assess landscape permeability and movement bottlenecks across the study region; (3) to estimate human-leopard conflict probabilities using spatial risk modeling; and (4) to identify safe and highrisk corridors, and possible conservation interventions.

\section{Methods}

Study area

Our study area (ca. $3132 \mathrm{~km}^{2}$ ) is situated in the eastern Alborz Mountains in northeastern Iran (Fig. 1). The area connects the Golestan National Park complex (including Golestan National Park GNP and its buffer zones Loveh Protected Area and Zav Protected Area) and Jahan Nama Protected Area (JNPA), two strongholds of the Persian leopard in southwest Asia (Kiabi et al. 2002). Only some parts of this range receive occasional patrols from the rangers of the Golestan provincial office of the Department of Environment. The main prey species of leopard in this area are bezoar goat (Capra aegagrus), red deer (Cervus elaphus), roe deer (Capreolus capreolus) and wild boar (Sus scrofa) (Ghoddousi et al. 2016). The study area is part of the Caucasus-Hyrcanian Biodiversity Hotspot and is covered by Hyrcanian temperate mixed forest. We focused on the mountainous part of the region (on average from 380-2300 $\mathrm{m}$ a.s.1.), as leopard occurrence in the lowlands is very rare and the landscape there has almost entirely been transformed into urban and agricultural areas. Moreover, there is a sharp environmental difference between the northern and southern slopes of the Alborz Mountains, with the southern slopes receiving less precipitation and thus being arid and without forests. We focused only on the northern slopes, which are more similar to the landscapes in western GNP and JNPA. 


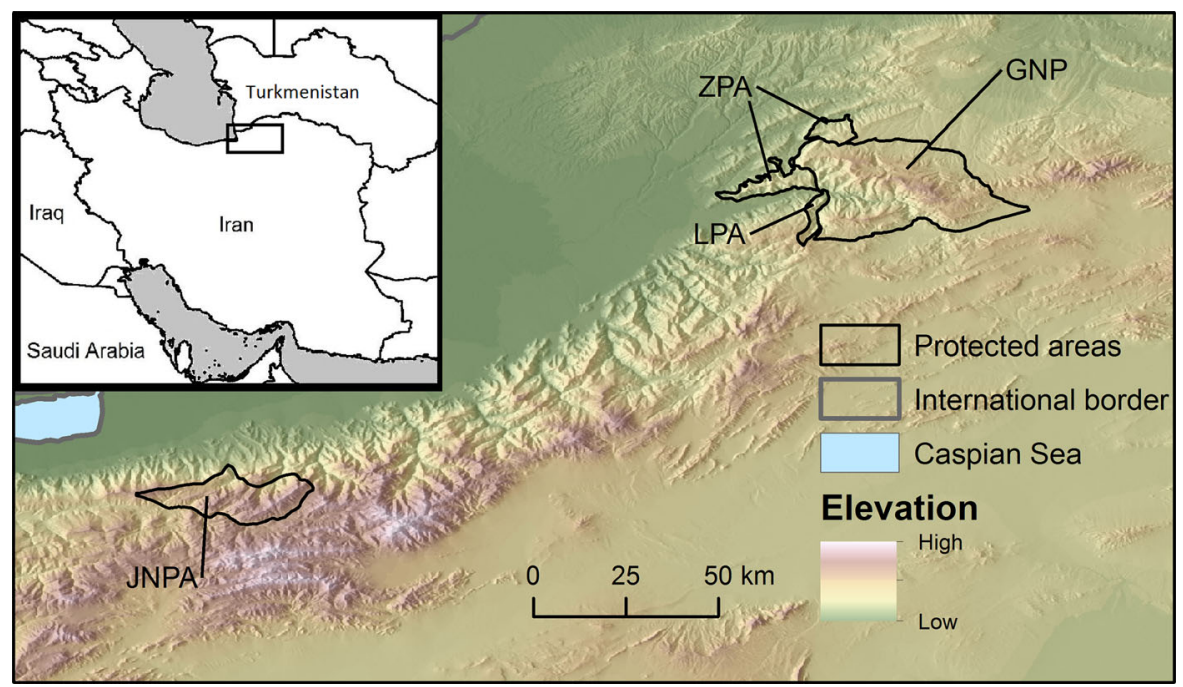

Fig. 1 Study area in the eastern Alborz Mountains, Iran (inset map; grey: water bodies) and the location of Golestan National Park (GNP), Loveh Protected Area (LPA), Zav Protected Area (ZPA), and Jahan Nama Protected Area (JNPA)

\section{Sampling design}

We used a grid system with $6 \times 6 \mathrm{~km}$ cells superimposed over the study area to identify sampling units (hereafter: cells). We chose this cell size following the recommendation (Beier 2019) on corridor width $>2$ $\mathrm{km}$ when connecting habitat patches $>80 \mathrm{~km}$ apart ( $>160 \mathrm{~km}$ aerial distance in our case). Moreover, such long corridors should consider a number of habitat patches where the species could temporarily reside (Beier 2019). This cell size is relevant considering the relatively large home range of Persian leopards, which is estimated at an average of around $100 \mathrm{~km}^{2}$ (Farhadinia et al. 2018). Our cell size is also in accordance with recommendations on occupancy modeling approach using interview data, where cell size should be a compromise between sampling effort (i.e., the typical travel distance covered by foot by interviewees) and detectability (see below) (MacKenzie et al. 2017; Petracca et al. 2018). Finally, previous large-scale corridor planning studies for wide-ranging species used similar cell sizes (e.g., $16-36 \mathrm{~km}^{2}$ for jaguar $P$. onca corridor planning in Central America; Petracca et al. 2018). We used a 50\% threshold for the natural vegetation coverage in each cell based on a land-cover map (see below) derived from Landsat 8 satellite images at 30-m resolution (Bleyhl et al. 2017). We removed cells below this threshold from our analysis since highly transformed areas may function as strong barriers to the movement of leopard and its prey (Bleyhl et al. 2017). We conducted all of our data collection and analysis in the remaining 74 cells.

Interview survey

We collected data on the presence of leopard, key prey species, and leopard depredation on livestock in our cells, using interviews with local communities from August to September 2015 and from February to October 2016. Surveys across larger landscapes can be very costly and difficult to implement using field observations of wildlife or camera trapping, and interview surveys can be a viable alternative in such situations (Zeller et al. 2011; Pillay et al. 2014; Martinez-Marti et al. 2016; Ghoshal et al. 2017). The use of interview data for wildlife surveys is especially successful when applied for relatively rare species with large body size, given appropriate statistical methods are used (Steger et al. 2017). We conducted interviews in one or two randomly chosen villages within each $36 \mathrm{~km}^{2}$ cell and aimed to collect information from at least four interviewees. Each interviewee represented a replicate, providing information for the cell surrounding his/her village (Zeller et al. 2011). If other neighboring cells were visited on a monthly basis by the interviewee, we conducted a separate interview related to that cell (Taubmann et al. 2015). We conducted interviews only with individuals 
who were knowledgeable about wildlife (e.g., regularly working outdoors), lived in the area for at least one year, and with a minimum residency of three months in the prior year. We gathered information from the interviewees on direct sightings of leopard and main prey species (i.e., bezoar goat, red deer, roe deer, and wild boar) and assigned them to the respective cells when the interviewee was able to distinguish the species based on pictures presented to them showing Iran's large mammals. Only direct observations by the interviewee were included, as we considered sightings by others or based on indirect evidence such as species' signs (e.g., tracks) unreliable. No other big cat or ungulate species than the study species exist in this area. Moreover, we recorded cases of leopard depredation on livestock in the prior year (Zeller et al. 2011). Wolves (Canis lupus) are also responsible for livestock depredation in the study area. However, we assume that the interviewees were skilled enough to distinguish between leopard and wolf depredation signs (killing by strangulation with throat bites vs. laceration of flanks and hind legs, respectively). When in doubt, we discarded ambiguous cases. Finally, we asked interviewees about their age, occupation, the period he/she has lived in the cell and the proportion of the prior year resided in the cell (Zeller et al. 2011). We received verbal consent from all interviewees before conducting interviews and assured them about the confidentiality and anonymity of their data.

\section{Occupancy modeling}

We fitted single-species, single-season occupancy models for leopard and four prey species using the unmarked package in R (Zeller et al. 2011; MacKenzie et al. 2017). As the assumption of population closure within the survey, required for occupancy states, could not be met due to long period of sightings (i.e., one year prior to the interview), we assumed that the occupancy states in each $36 \mathrm{~km}^{2}$ cell represent the habitat use (MacKenzie and Nichols 2004). We created species detection matrices by assigning the detection/non-detection histories for leopard and prey species in different cells based on interviewees' sightings and treating each interview as a separate sampling event in that cell (Zeller et al. 2011). We addressed the potential false-positive bias from misidentifications in interviewee responses using the
occuFP function that allows specifying factors that may influence such detections (Fiske and Chandler 2011; Miller et al. 2011; Chambert et al. 2015; Petracca et al. 2018). We assumed that our data included both certain detections (without false-positive bias) and uncertain detections (with false-positive bias) (Miller et al. 2011), and considered sightings by rangers and hunters as having a lower probability of false-positive bias (due to higher expertise in wildlife encounters and identification) compared to other interviewees (Miller et al. 2011; Martinez-Marti et al. 2016; Ghoshal et al. 2017; Johnston et al. 2018). We marked the detections by this observer category as 'certain' in the detection matrices ( Pillay et al. 2014; Chambert et al. 2015).

We developed a-priori hypotheses regarding factors that could affect species' detection $(\rho)$ and habitat use $(\psi)$. We assumed effort (i.e., days of the prior year spent in the cell) and residence (i.e., number of years of familiarity with a sampling unit) covariates to influence $\rho$ (Zeller et al. 2011). Regarding $\psi$, we hypothesized potential influence by land cover, elevation, road density, prey availability (only in leopard models), ruggedness and distance to protected areas (Petracca et al. 2014; Athreya et al. 2015; Abade et al. 2018). A detailed description of each covariate and their hypothesized effects on $\rho$ and $\psi$ are provided in Table 1 . We tested all covariates for autocorrelation using the Pearson correlation test (cut-off point $r=|0.60|)$. Moreover, we scaled all the covariates prior to the analyses to have a unit variance and minimize overdispersion (MacKenzie et al. 2017).

We tested different scenarios to calculate prey availability (bezoar goat, red deer, roe deer, and wild boar) per cell: (1) prey richness (number of prey species reported by interviewees); (2) single-species and (3) cumulative habitat use (sum of occupancy model estimates); and (4) cumulative catch-per-uniteffort (CPUE; multiplying the number of independent detections by the species' average biomass, divided by the number of interviewees) (Abade et al. 2018; Petracca et al. 2018). We obtained prey biomass figures from Lumetsberger et al. (2017). Using univariate occupancy models, CPUE performed best in explaining leopard $\psi$ (Table 2), and therefore, we used this covariate as prey availability in the leopard models.

We used a multi-step approach to specify our occupancy model parameters by first building models 
Table 1 Covariates used in the occupancy models, with the hypothesized effect of each covariate on detection probability $(\rho)$ and habitat use $(\psi)$ of leopard and prey species

\begin{tabular}{|c|c|c|c|c|}
\hline $\begin{array}{l}\text { Model } \\
\text { process }\end{array}$ & Covariate & Description & Data source & $\begin{array}{l}\text { Hypothesized } \\
\text { influence }\end{array}$ \\
\hline \multirow{2}{*}{$\begin{array}{l}\text { Detection } \\
(\rho)\end{array}$} & Effort & Proportion of the prior year spent in the cell & Interview data & + \\
\hline & Residence & Number of years of familiarity with the cell & Interview data & + \\
\hline \multirow[t]{7}{*}{$\begin{array}{l}\text { Habitat } \\
\text { use }(\psi)\end{array}$} & Prey availability ${ }^{\mathrm{a}}$ & $\begin{array}{l}\text { The cumulative catch-per-unit-effort for three large } \\
\text { prey species in cell }{ }^{\mathrm{b}}\end{array}$ & Interview data & + \\
\hline & $\begin{array}{l}\text { Distance to } \\
\text { protected areas }\end{array}$ & $\begin{array}{l}\text { Nearest distance }(\mathrm{km}) \text { to protected area borders } \\
\text { from cell centroid }\end{array}$ & $\begin{array}{l}\text { World database on } \\
\text { protected Areas }\end{array}$ & - \\
\hline & Forest $^{\mathrm{d}}$ & Proportion of forest in cell & Land-cover map & + \\
\hline & Cropland $^{\mathrm{d}}$ & Proportion of cropland in cell & Land-cover map & - \\
\hline & Road density & Length $(\mathrm{km})$ of primary roads in cell & Google earth & - \\
\hline & Elevation & Average elevation $(\mathrm{m})$ in cell & SRTM $^{\mathrm{e}}$ & $+/-^{\mathrm{f}}$ \\
\hline & Ruggedness & Average ruggedness index in cell & SRTM $^{\mathrm{e}}$ & + \\
\hline
\end{tabular}

${ }^{\mathrm{a}}$ Only considered in the leopard models

${ }^{\mathrm{b}}$ Biomass of prey species based on Lumetsberger et al. (2017): bezoar goat $36 \mathrm{~kg}$, roe deer $20 \mathrm{~kg}$, red deer $99 \mathrm{~kg}$

${ }^{\mathrm{c}}$ Source: www.protectedplanet.net

${ }^{\mathrm{d}}$ Due to the high correlation between forest and cropland layers, we only used either of them in each model

eSource: Shuttle Radar Topography Mission (https://search.earthdata.nasa.gov)

${ }^{\mathrm{f}}$ We hypothesized that our study species could respond differently to elevation according to our field observations

using covariates influencing $\rho$ while maintaining $\psi$ as constant. Then, we held the covariates in the top $\rho$ models constant and built models that influenced $\psi$ (MacKenzie et al. 2017). We evaluated univariate occupancy models based on a-priori hypotheses and then made ecologically-relevant combinations of covariates to assess their influence on $\psi$ (see Online Appendix S1 for the full set of models tested). We ranked models based on their Akaike Information Criterion corrected for small sample size (AICc) (Burnham and Anderson 2002). We used $\Delta$ AICc $<2$ criteria to select the best models and applied model averaging technique to estimate probabilities of $\psi$ and $\rho$ when more than one model fit our criteria (Burnham and Anderson 2002). We also compared a naïve model ( $\psi_{\text {naive }}:$ proportion of cells with at least one detection)

Table 2 Comparison of model performance of different prey covariate scenarios in explaining leopard habitat use $(\psi)$

\begin{tabular}{llllll}
\hline Prey covariate scenarios & $\mathrm{K}^{\mathrm{a}}$ & $\mathrm{AICc}^{\mathrm{b}}$ & $\Delta \mathrm{AICc}^{\mathrm{c}}$ & AICc weight & Log-likelihood \\
\hline CPUE & 5 & 346.99 & 0 & 0.64 & -168.02 \\
Prey richness & 5 & 350.08 & 3.09 & 0.14 & -169.56 \\
Bezoar goat & 5 & 352.20 & 5.21 & 0.05 & -170.63 \\
Cumulative prey & 5 & 352.41 & 5.42 & 0.04 & -170.73 \\
Roe deer & 5 & 352.54 & 5.56 & 0.04 & -170.80 \\
Red deer & 5 & 353.05 & 6.06 & 0.03 & -171.05 \\
\hline
\end{tabular}

Scenarios: $C P U E$, cumulative catch-per-unit-effort for all prey species with biomass data from Lumetsberger et al. (2017); cumulative prey, cumulative habitat use estimates from occupancy models; roe deer, red deer, bezoar goat, single-species habitat use estimates from occupancy models; prey richness, number of prey species reported by interviewees per cell

${ }^{a}$ Number of parameters in the model

${ }^{\mathrm{b}}$ Akaike information criterion corrected for small sample size

${ }^{\mathrm{c}}$ Difference in AICc value relative to the best model 
with and without false positive detection $\left(\rho_{10}\right)$ to assess the impact of this bias on occupancy estimates (Petracca et al. 2018).

\section{Landscape permeability}

To assess landscape permeability in our study region, we estimated the landscape resistance to species movement between GNP and JNPA. First, we mapped six land-cover classes using Landsat 8 satellite images with 30-m spatial resolution: forest, rangeland, cropland, built-up, sparse vegetation, and water (see Online Appendix S2 for details on the land-cover mapping). We translated our land-cover map into a surface characterizing resistance to leopard movement (Zeller et al. 2012; Dutta et al. 2016) by assigning resistance values to land-cover classes representing vegetation formations (i.e., forest, rangeland, cropland, and sparse vegetation) based on a survey among 27 wildlife experts (Bleyhl et al. 2017). Resistance values of these vegetated land-cover classes were allowed to range from one (most permeable) to ten (least permeable). To reach a consensus across the expert group, we calculated median resistance values per land-cover class (Bleyhl et al. 2017). Next, we added paved roads as partial barriers, assigning all 30-m cells containing a major road a resistance value of 100 (a value tested previously in a similar landscape for the same study species; Bleyhl et al. 2017). Finally, we considered the land-cover classes built-up and larger water bodies as total barriers (i.e., no movement was allowed through these land covers). We averaged resistance values for each $36 \mathrm{~km}^{2}$ cell.

To identify bottlenecks across the landscape at 30-m spatial resolution, we first identified the leastcost pathway between the protected areas (i.e., the single-pixel-wide path with the lowest cumulative resistance). We then mapped areas around this pathway with a cumulative resistance of $<100$ times higher, which is a threshold tested and used in previous studies (Dutta et al. 2016; Bleyhl et al. 2017). We conducted both of these analyses using the Linkage Mapper Toolkit (McRae et al. 2008) in ArcGIS 10.5 (ESRI, Redlands, CA, USA). We assessed connectivity between two nodes only, as we were only interested in the linkages between two protected areas. We then applied circuit theory within our pathways to identify movement bottlenecks using the Pinchpoint Mapper tool in the Linkage Mapper Toolkit. This method measures the current (i.e., likelihood of a species passing) between nodes (in our case protected areas) across the landscape, considering the resistance of the landscape (McRae et al. 2008). High currents indicate a lack of alternative paths, and therefore, potential bottlenecks within a corridor. We defined bottlenecks as areas with a current density higher than the mean plus two standard deviations (Bleyhl et al. 2017). Finally, we calculated the number of bottlenecks for each $36 \mathrm{~km}^{2}$ cell.

\section{Conflict risk modeling}

To quantify and map associations between humanleopard conflict and landscape characteristics, we used generalized linear models using the stats package in $\mathrm{R}$ (Miller 2015). We derived the binomial presence or absence of conflict (i.e., leopard depredation on livestock) in each cell from our interview data. Leopards are ambush hunters and benefit from intermediate cover levels (Balme et al. 2007). Therefore, in addition to the environmental covariates used in the occupancy modeling, we calculated variables reflecting forest type and fragmentation in each cell, as we hypothesized these variables may influence leopard feeding habitat selection, wild and domestic prey availability, and consequently the depredation risk on livestock (Balme et al. 2007; Carvalho et al. 2015; Miller 2015; Acharya et al. 2017). A detailed description of all the variables tested and their hypothesized effects on conflict risk is provided in Table 3. We used Morphological Spatial Pattern Analysis (MSPA) (Vogt and Riitters 2017) on our land-cover map to measure the share of core forest as well as connecting forest patches per cell. Core forest was defined as patches larger than $2 \mathrm{~km}^{2}$ (Vogt and Riitters 2017), with an adjacent forest edge of $<300$ m (10 forest pixels in our Landsat-based map). Connecting forest was assigned to those patches $\left(>2 \mathrm{~km}^{2}\right)$ that were $>300 \mathrm{~m}$ from the nearest forest patch. Additionally, we calculated the median forest patch area, forest patch density, forest patch edge, core forest patch edge, and core forest shape index per cell using FRAGSTATS (McGarigal et al. 2012) as indicators of forest fragmentation. We tested for collinearity among all covariates using the Pearson correlation test $(\mathrm{r}<|0.60|)$. We applied a similar model selection procedure as in our occupancy modeling. We evaluated model results using the area under the 
Table 3 Variables used in the conflict risk models, with the hypothesized effect of each variable on depredation risk of leopard on livestock

\begin{tabular}{|c|c|c|}
\hline Variable & Description & $\begin{array}{l}\text { Hypothesized } \\
\text { influence }\end{array}$ \\
\hline Forest & Proportion of forest in cell & + \\
\hline Cropland & Proportion of cropland in cell & - \\
\hline Core forest & $\begin{array}{l}\text { Proportion of patches larger than } 2 \mathrm{~km}^{2} \text { with an adjacent forest edge of }<300 \mathrm{~m} \text { (10 forest } \\
\text { pixels in the Landsat-based map) in cell }\end{array}$ & - \\
\hline Connect forest & Proportion of patches larger than $2 \mathrm{~km}^{2}$ with an adjacent forest patch of $>300 \mathrm{~m}$ in cell & + \\
\hline Forest edge & Proportion of a $300 \mathrm{~m}$ wide edge area of forest patch in cell & + \\
\hline Core forest edge & Proportion of a $300 \mathrm{~m}$ wide edge area of core forest patch in cell & + \\
\hline $\begin{array}{l}\text { Core forest } \\
\text { shape index }\end{array}$ & $\begin{array}{l}\text { Normalized ratio of core forest patch edge (i.e., patch perimeters) to maximally clumped- } \\
\text { shaped edge in cell }\end{array}$ & + \\
\hline $\begin{array}{l}\text { Forest patch } \\
\text { density }\end{array}$ & Number of forest patches by the area of forest patches in cell & + \\
\hline Forest patch area & Median forest patch area in cell & - \\
\hline
\end{tabular}

receiver-operating curve (AUC) with tenfold crossvalidation. We randomly split the data into 10 folds containing equal number of depredation cases, and created the training models by eliminating each fold in turn. In each turn, we used the removed fold for testing the model derived from the remaining training folds.

Identification of habitat patches and safe corridors

We used a multi-criteria approach to identify habitat patches and corridors (Fig. 2) ( Rödder et al. 2016; Cushman et al. 2018). We used Jenks natural breaks to categorize the maps of leopard habitat use, landscape resistance, bottleneck numbers, and human-leopard conflict intensity. Jenks natural breaks is a data-driven classification method that identifies natural groupings inherent in the data. We chose this method over equal or expert-based thresholds as our input surfaces were not normally distributed. We classified $36 \mathrm{~km}^{2}$ cells into three categories (i.e., low, medium, high) by finding points where between-group variability was highest while within-group variability was minimized using ArcGIS 10.5. 'Habitat patches' are areas where leopards are prevalent, and thus can be the origin or destination of dispersers (Kramer-Schadt et al. 2011). Specifically, we classified habitat patches as cells with a high probability of leopard habitat use (Zeller et al. 2011) and all other cells were classified as 'matrix' (Kramer-Schadt et al. 2011; Rödder et al. 2016). We used the Wilcoxon signed-rank test to assess differences in the levels of cumulative prey habitat use, landscape resistance and conflict probabilities between the habitat patches and the matrix.

We classified 'safe corridors' by identifying matrix cells characterized by low or medium levels of landscape resistance and low or medium levels of conflict risk. All remaining cells were relabeled as 'severed corridors' (Riggio and Caro 2017). Finally, within the severed corridors, we identified 'high-risk corridors' as areas with the highest number of bottlenecks, which require urgent conservation intervention due to the absence of alternative dispersal paths, high landscape resistance and conflict risk (Taubmann et al. 2015). To assess the sensitivity of our classification, we also did a re-classification using geometrical intervals (another data-driven classifier algorithm that minimizes the square sum of element per class) instead of natural breaks, and quantified the differences.

\section{Results}

\section{Interview survey}

We conducted 208 semi-structured interviews in 69 cells. We were unable to collect data from five cells due to inaccessibility or lack of settlements, and therefore, those cells were removed from the analysis. Within the sampled cells, on average around 3.0 


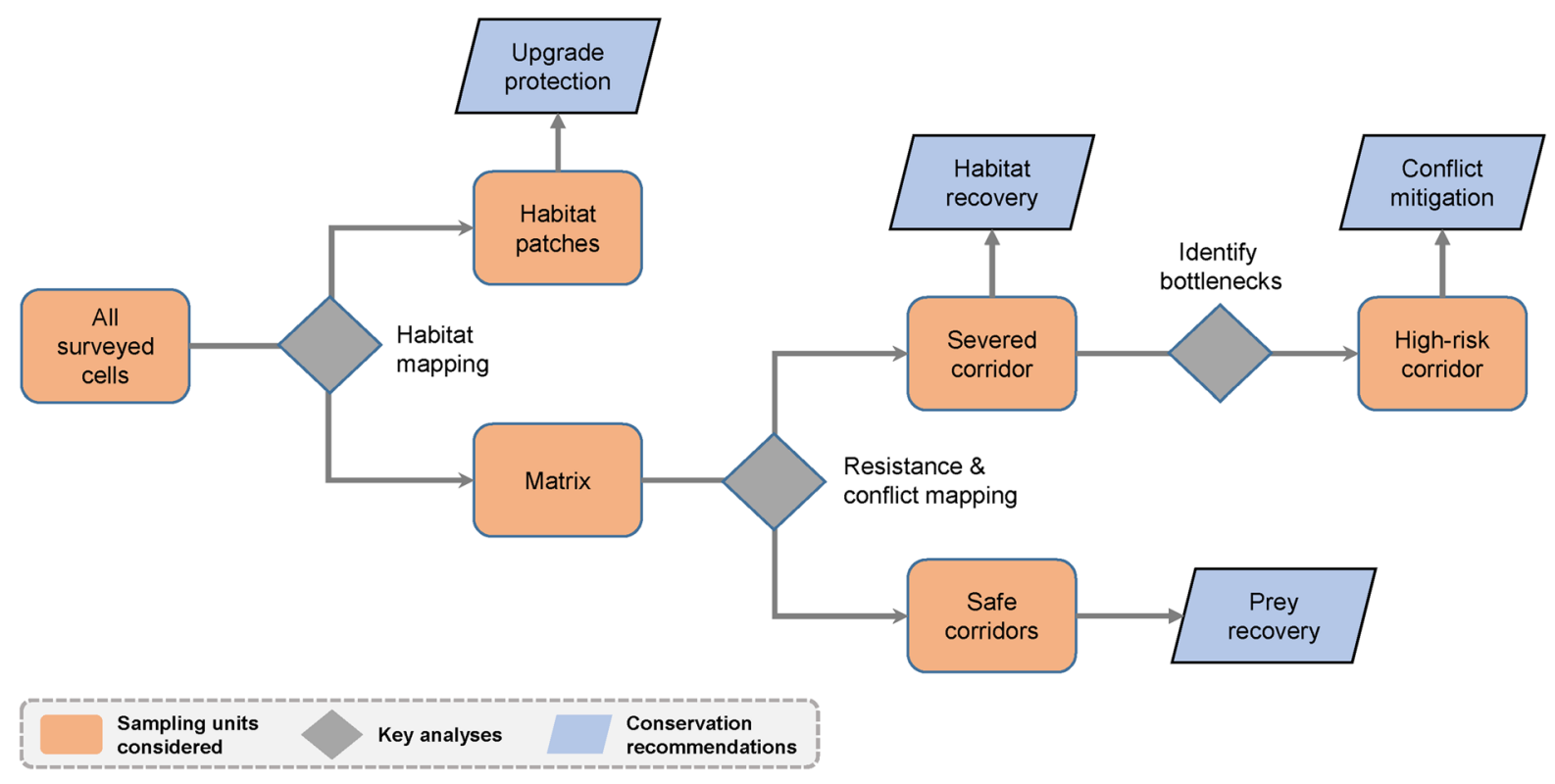

Fig. 2 Flowchart of the step-wise multi-criteria approach to identify habitat patches, safe and high-risk corridors, and their respective conservation recommendations

questionnaires were completed. Interviewees were all male and between 17 and 80 years old with a mean age of 41.1 years. Interviewees spent on average 309 days of the year within their respective cells and had on average 38.9 years of living experience in the area. The interviewees were mostly shepherds (44.9\%), but also farmers $(26.8 \%)$, rangers $(12.2 \%)$, foresters $(6.3 \%)$, hunters $(6.3 \%)$ and porters $(3.4 \%)$. Leopards were sighted in 51 of the 69 cells $(73.9 \%)$ and leopard depredation on livestock was reported in 24 cells $(34.8 \%)$. The most often-sighted wild prey was wild boar, which occurred in all cells, followed by roe deer $(63.8 \%)$, red deer $(42.0 \%)$ and bezoar goat $(26.1 \%)$. We removed wild boar from the analyses due to their ubiquitous distribution.

\section{Occupancy modeling}

None of the detection $(\rho)$ covariates were selected in our top models. The naïve occupancy $\left(\psi_{\text {naive }}\right)$ dropped by around $14 \%, 9 \%, 1 \%$ and $5 \%$ for leopard, red deer, roe deer and bezoar goat, respectively, when considering the potential false-positive bias $\left(\rho_{10}\right)$ in our interview data. The most parsimonious habitat use $(\psi)$ model for leopard included prey availability and elevation covariates (Table 4). It suggests leopards avoid higher elevations and their $\psi$ increases with higher prey availability. Agriculture and distance from protected areas were the main factors negatively influencing $\psi$ for red deer and roe deer (Table 4). In addition, $\psi$ of red deer was positively associated with elevation (Table 4). The $\psi$ of bezoar goat was positively associated with the ruggedness of the cells and inversely related to the distance from protected areas (Table 4). Projecting our final model to all cells showed that high leopard habitat use $(>0.68)$ occurred in 20 cells (29\% of all cells; Fig. 3). High cumulative prey habitat use ( $>1.14$; range $0-1.99$ ) occurred in 14 cells (20\%; Fig. 3 ). We identified habitat patches based on high leopard habitat use, and considered the remaining cells $(n=49)$ as matrix (Fig. 4). The cumulative prey habitat use was significantly higher $(Z=723, p<0.01)$ in habitat patches compared to the matrix.

\section{Landscape permeability}

In our land-cover map, forest was the most widespread class $(66.7 \%)$ followed by rangeland $(18.6 \%)$, cropland $(12.8 \%)$, sparse vegetation (1\%), built-up $(0.9 \%)$ and water $(<0.05 \%$; Fig. S1 in Online Appendix). The mean landscape resistance in each cell based on our land-cover maps ranged from 1 to 5.05, which revealed high landscape resistance in the eastern parts 
Table 4 Top occupancy models of leopard and prey species with habitat use $(\psi)$ and detection probability $(\rho)$ covariates

\begin{tabular}{|c|c|c|c|c|c|c|c|}
\hline Species & Model & $\begin{array}{l}\text { Intercept } \\
\left(\mathrm{SE}^{\mathrm{a}}\right)\end{array}$ & Prey $\left(\mathrm{SE}^{\mathrm{a}}\right)$ & Elev. $\left(\mathrm{SE}^{\mathrm{a}}\right)$ & $\mathrm{PA}\left(\mathrm{SE}^{\mathrm{a}}\right)$ & Crop $\left(\mathrm{SE}^{\mathrm{a}}\right)$ & $\begin{array}{l}\text { Rugged } \\
\left(\mathrm{SE}^{\mathrm{a}}\right)\end{array}$ \\
\hline Leopard & $\Psi$ (prey + elev.), $\rho()$. & $0.13(0.64)$ & $1.85(0.88)$ & $-1.24(0.76)$ & - & - & - \\
\hline Red deer & $\Psi($ crop + elev. + PA $), \rho()$. & $-1.54(0.86)$ & NA & $0.86(0.46)$ & $-0.85(0.43)$ & $-1.95(1.33)$ & - \\
\hline Roe deer & $\Psi($ crop $+\mathrm{PA}), \rho()$. & $1.03(0.59)$ & NA & - & $-2.15(0.89)$ & $-1.99(0.68)$ & - \\
\hline Bezoar goat & $\Psi(\mathrm{PA}+$ rugged. $), \rho()$. & $-9.09(6.35)$ & NA & - & $-7.99(5.76)$ & - & $4.81(4.43)$ \\
\hline
\end{tabular}

The habitat use $(\psi)$ covariates: prey, the cumulative catch-per-unit-effort for three large prey species; elev., average elevation (m) in cell; $P A$, distance $(\mathrm{km})$ to protected areas from cell centroid; crop, proportion of cropland in cell; rugged, average ruggedness index in cell

${ }^{\text {a }}$ Standard error

(a)
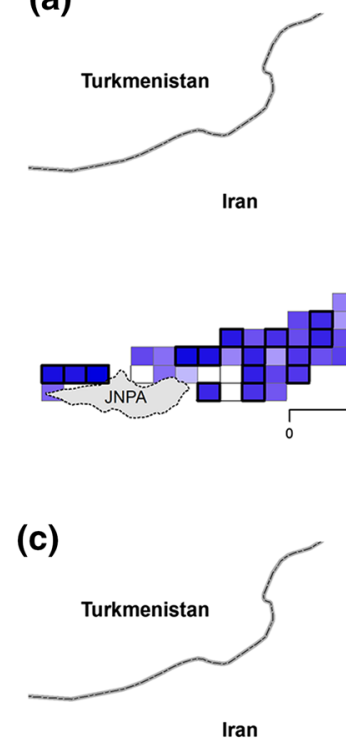

(c)

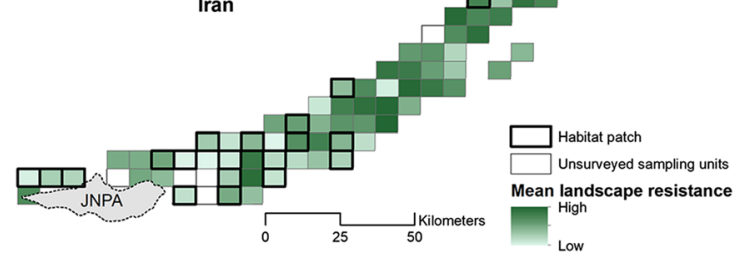

Fig. 3 Estimated leopard (a) and prey (b) habitat uses, mean landscape resistance (c) and human-leopard conflict risk (d) between Golestan National Park (GNP) and Jahan Nama Protected Area (JNPA), Iran. Habitat patch: sampling units with

of the study area (Fig. 3). However, the landscape resistance $(Z=270, p<0.01)$ was significantly lower in the habitat patches compared to the matrix.

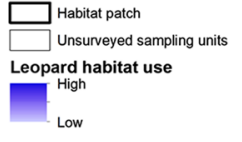

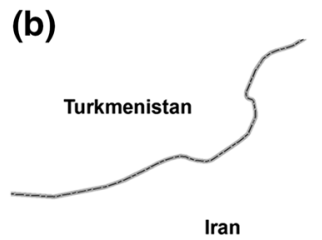
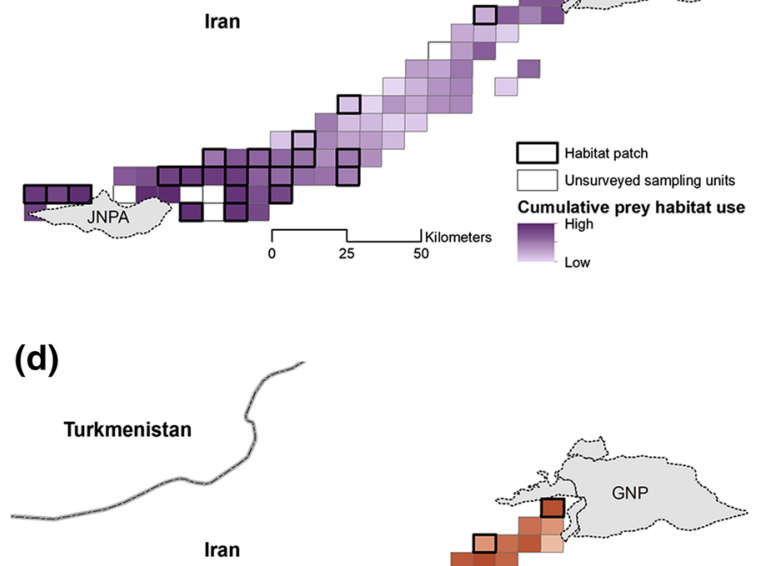

\section{Conflict risk}

The top conflict risk model included cropland, connecting forest and median forest patch area (Table 5). This model revealed a positive association of cropland with conflict intensity, whereas median 


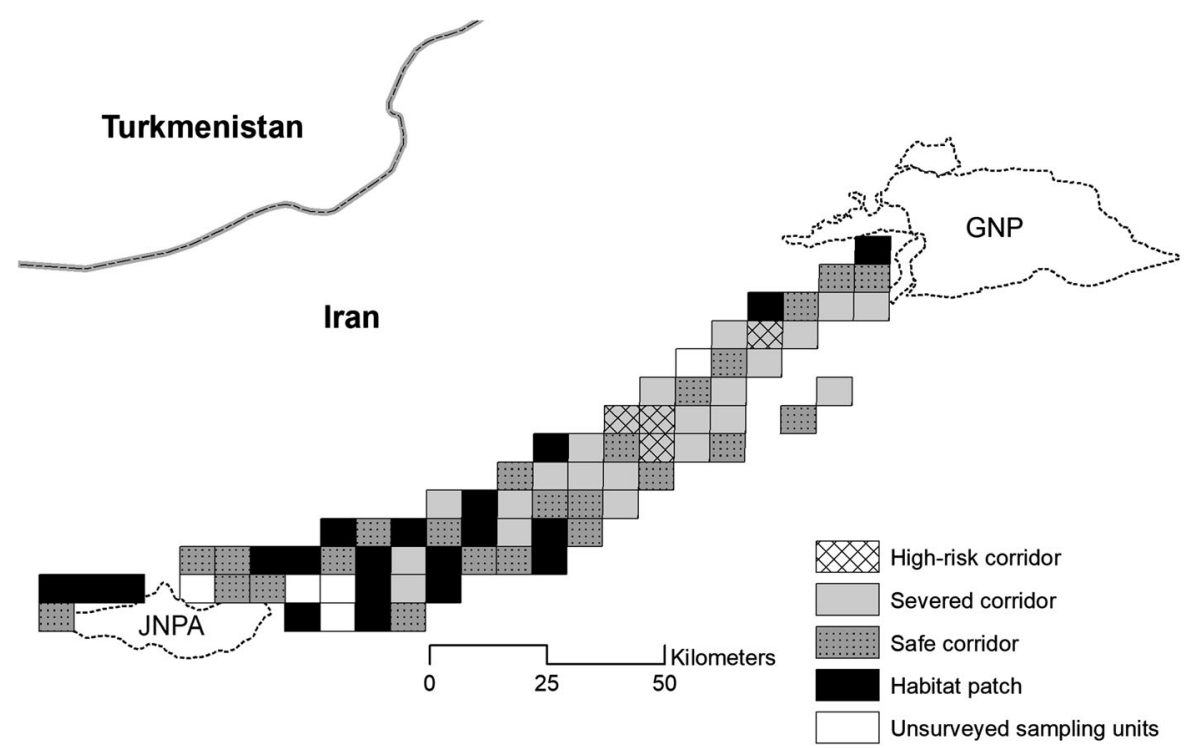

Fig. 4 Location of habitat patches, safe, severed, and high-risk corridors between Golestan National Park (GNP) and Jahan Nama Protected Area (JNPA), Iran

forest patch area and connecting forest were associated with lower conflict rates. The AUC for the best model was 0.73 . The conflict risk was lower in the habitat patches compared to the matrix but this difference was not statistically significant $(Z=416$, $p=0.33)$.

\section{Safe corridors}

We classified 24 matrix cells (49\% of all matrix cells) with low or medium conflict risk $(<0.56)$ and low or medium landscape resistance $(<3.47)$ as safe corridors and identified the remaining cells $(n=25)$ as severed corridors. The identified safe corridor cells could fill the connectivity gap between some of the habitat patches but were absent from the eastern parts of the study area (Fig. 4). When not accounting for the conflict risk and using the same landscape resistance threshold, the safe corridor cells were overestimated by $36.7 \%$. We identified four cells with a high number of bottlenecks $(>1377)$ in the severed corridors, indicating high-risk corridors that are priority areas for conflict mitigation measures (Fig. 4). The results of the sensitivity analysis of our classification methodology showed that habitat patches and safe corridors identified based on geometrical intervals had $95 \%$ and $79 \%$ overlap with the results of the Jenks method, respectively.

\section{Discussion}

Large carnivores in human-dominated landscapes typically cannot persist inside protected areas alone and critically depend on habitat outside protected areas, as well as on functioning corridors between them (Ripple et al. 2014). We show how assessments of habitat, landscape permeability, and human-carnivore conflict risk can be combined to identify safe and high-risk corridors for large carnivores in humandominated landscapes. Using the example of Persian leopards in northeastern Iran, we also demonstrate how leveraging community observations and remotely-collected data can allow for such analyses in a data-limited environment, thus ultimately guiding conservation planning for maintaining a wide-ranging threatened species outside protected areas. This is relevant, as many areas where conflict between large carnivores and people are high face such data limitations. Our analyses further provide insights on the reciprocal relationship between human-wildlife conflict and connectivity as well as the impact of agricultural land use on the persistence of ungulate species and consequently large carnivores that depend on them as prey.

A first major insight from our work was that ignoring human-leopard conflict in connectivity assessments may lead to a substantial overestimation 
Table 5 Parameters of the best-performing generalized linear model of human-leopard conflict

\begin{tabular}{lcccccc}
\hline Coefficient & Estimate & $\mathrm{SD}^{\mathrm{a}}$ & $Z$ value & $p$ value & Odds & $95 \% \mathrm{CI}^{\mathrm{b}}$ \\
\hline Intercept & 0.32 & 0.61 & 0.52 & 0.59 & - & - \\
Connecting forest & -0.13 & 0.05 & -2.51 & 0.01 & 0.87 & $0.77-0.95$ \\
Cropland & 0.11 & 0.05 & 2.23 & 0.02 & 1.12 & $1.02-1.26$ \\
Forest patch area & -0.24 & 0.11 & -2.14 & 0.03 & 0.78 & $0.60-0.96$ \\
\hline
\end{tabular}

Covariates: connecting forest, forest patches larger than $2 \mathrm{~km}^{2}$ with $>300 \mathrm{~m}$ distance from the nearest forest in the land-cover map; cropland, proportion of cropland in cell; forest patch area, median forest patch area in cell from land-cover map

${ }^{\text {a }}$ Standard deviation

${ }^{\mathrm{b}}$ Confidence intervals

of the extent of the corridor and the functional connectivity among habitat patches. Many leopard dispersal bottlenecks in the eastern Alborz Mountains were located in areas with high conflict risk (i.e., highrisk corridors), where the persecution of leopard is likely (Kiabi et al. 2002; Lennox et al. 2018), and local extinction risk is high (Jędrzejewski et al. 2017). These landscapes may act as 'ecological traps' when animals are funneled through them (Little et al. 2002; Kramer-Schadt et al. 2011; Northrup et al. 2012) and consequently, put dispersing individuals at risk of conflict. Moreover, the behavioral constraints to dispersal, such as avoidance of unsafe landscapes (Gehr et al. 2017) may limit the permeability of highrisk corridors (Goswami and Vasudev 2017). Therefore, our study reinforces other calls ( LaPoint et al. 2013; Goswami and Vasudev 2017; Festa-Bianchet 2018) for more deeply considering ecological as well as intrinsic constraints for corridor identification in human-dominated landscapes, some of which might be difficult to measure with remote sensing and conventional habitat assessment techniques (Scharf et al. 2018). Our study shows how a rapid and low-cost assessment based on local interviews can alleviate this issue and help in the identification of conservation priorities in conflict-prone landscapes.

A second insight from our analyses was a better understanding of the influence of agricultural lands and forest fragmentation on human-carnivore conflicts in human-dominated landscapes. In our study, conflict probability was clearly associated with the share of croplands in each cell, which has been reported in other human-dominated landscapes (Northrup et al. 2012). Agricultural lands on the periphery of core habitats offer domestic prey as a food source and increase the probability of livestock depredation by leopard (Abade et al. 2018). Moreover, the prey depletion in these landscapes from habitat loss and/or poaching may trigger a higher rate of livestock depredation by big cats, as suggested in a global review (Khorozyan et al. 2015). Our results also showed a positive association between forest fragmentation and the probability of livestock depredation. Other studies ( Michalski et al. 2006; Carvalho et al. 2015; Acharya et al. 2017), similarly showed that forest fragmentation leads to the creation of heterogeneous landscapes and higher presence of livestock, both of which increase the probability of conflict between humans and large carnivores. However, the negative influence of connecting forest on conflict probabilities was contrary to our expectations, which may be due to the persistence of wild prey (roe deer and wild boar) in these forest fragments.

A third key finding of our work was the negative impact of agriculture on the occurrence of two prey species, which may have indirect negative consequences for leopards as well. Only about a third of the study area between Golestan National Park and Jahan Nama Protected Area could be considered as highly used by the leopard, and the eastern part of the study area, which has experienced a higher rate of land-use change, is likely devoid of resident leopard and prey species (except wild boar). This result stands in contrast to previous studies (Odden et al. 2014; Kshettry et al. 2017), showing that leopards may use modified landscapes and agroecosystems as habitat. Prey availability, as one of the most important drivers of leopard habitat use in our study, may explain this as it may be the true limiting factor in modified landscapes. In our study, the habitat use of prey 
species was mostly negatively affected by agricultural landscapes. This reflects the importance of habitat loss from land-use change as a threat to the existence of ungulate species, especially when it coincides with poaching (Benitez-Lopez et al. 2017; Romero-Muñoz et al. 2019), which ultimately impacts large carnivores. In other human-dominated landscapes, however, prey can be abundant (Chapron et al. 2014), which can explain why our results on the impact of agricultural extent on large carnivore existence diverge from prior studies.

Despite the absence of habitat patches in the modified landscape, these areas may still be valuable as dispersal corridors (Vanbianchi et al. 2018). However, low landscape permeability due to the existence of roads and residential areas pose major barriers to leopard dispersal in the eastern part of the study area. The high potential for agricultural expansion and intensification in this fertile region (Ghoddousi et al. 2017) may further isolate protected areas, impacting habitat connectivity of leopard. These results highlight the effect of structural landscape changes on habitat use and connectivity of wideranging species, especially where they interplay with other threats such as poaching.

Some possible drawbacks and room for improvement of our approach need mentioning. First, integrating different methodologies across various scales is challenging and we acknowledge simplifications in the classification of habitat patches and safe corridors. However, using Jenks and geometrical intervals classification methods, we showed that the choice of algorithm had a minor influence on our final results. Second, we sought to address the potential falsepositive bias by assuming a higher reliability of detections by rangers and hunters compared to other interviewees. Complete elimination of false-positive bias does not seem possible (Johnston et al. 2018), and we acknowledge that there is likely remaining misidentification error in data from rangers and hunters. However, considering the higher expertise in wildlife identifications among this group (Johnston et al. 2018) should reduce false-positive bias (Pillay et al. 2014). Moreover, we cannot completely rule out deliberate falsification of detections by interviewees (Pillay et al. 2014). However, the effects of falsepositive probabilities on naïve occupancies showed the necessity of considering this bias in the analysis of interview data (Petracca et al. 2018). Third, we acknowledge that the use of empirical movement data for parameterizing our resistance surfaces, instead of expert knowledge in our case, would have been desirable (Stevenson-Holt et al. 2014). However, such data (e.g., GPS telemetry data) were not available in our study. In the absence of such data, developing resistance layers based on expert knowledge is a viable alternative (Beier et al. 2008; Zeller et al. 2012) and often produce similar results to empirical movement models (Keeley et al. 2016; Aylward et al. 2018). Finally, the prey species in our study may use smaller areas than our cell size, which may bias our inferences by overestimating the habitat use of these species. However, such cell size has been successfully tested in multi-species settings of large carnivores and prey in previous studies (Zeller et al. 2011; Petracca et al. 2014).

Our results indicate a range of concrete conservation and landscape planning recommendations based on the intensities of species' habitat use, landscape permeability, and conflict risk. First, we recommend upgrading the protection measures in the habitat patches due to the higher habitat use of leopard. Present protected areas in Golestan Province are insufficient for the protection of the leopard's ungulate prey species (Momeni Dehghani et al. 2013), and the identified habitat patches in our study may represent suitable candidates for the expansion of the protected area network. The establishment of a protected area could provide the necessary law enforcement to curb poaching and potential land-use change. Second, safe corridors, as areas with low conflict risk and landscape resistance, require conservation interventions related to poaching mitigation, prey recovery, and protection from development (Cushman et al. 2018). Third, highrisk corridors may represent 'ecological traps' due to high conflict risk and the absence of alternative dispersal paths. These areas require urgent conflict mitigation measures to reduce the actual and perceived risk of human-leopard conflict (Broekhuis et al. 2017; Cushman et al. 2018), which are critical for the longterm persistence of leopards in the Caucasus-Hyrcanian ecoregion. Compensation to farmers for livestock losses due to leopards and/or preventive measures such as improved husbandry methods (e.g., secure night corral, education of shepherds and better guarding dogs) are recommended to reduce the chance of depredation and lethal control (Krafte Holland et al. 2018; van Eeden et al. 2018). Finally, cells identified 
as severed corridors require habitat recovery and prevention of further land-use change and forest fragmentation. For the persistence of threatened wide-ranging carnivores in the human-dominated landscapes, retaining native habitat within agroecosystems is crucial (Ferreira et al. 2018). While we derive these recommendations for our case study of Persian leopards in northeastern Iran, these recommendations are likely equally valid for other regions where large carnivores depend on corridors in humandominated landscapes, and where human-carnivore conflict may undermine the effectiveness of these corridors.

More broadly, our study highlights a low-cost and effective way to improve connectivity assessments by considering ecological and behavioral constraints to dispersal, such as human-carnivore conflict (LaPoint et al. 2013; Goswami and Vasudev 2017). Our approach can thus deliver a scientific basis for corridor planning outside protected areas by combining habitat assessment, landscape permeability, and conflict risk mapping.

Acknowledgements Open Access funding provided by Projekt DEAL. We thank all interviewees who accepted participation in this study. Moreover, we thank the rangers and staff of the Golestan provincial office of the Department of Environment for assisting us in the implementation of this project. This project was carried out with the approval of the Golestan provincial office of the Department of Environment. We appreciate the financial support by the German Research Foundation (DFG; project PArCS \#409732304). We thank L. Petracca, F. Poetzschner, and S. Shokri for help with data preparation. Four anonymous reviewers provided very helpful and constructive comments and we are grateful for their efforts.

Open Access This article is licensed under a Creative Commons Attribution 4.0 International License, which permits use, sharing, adaptation, distribution and reproduction in any medium or format, as long as you give appropriate credit to the original author(s) and the source, provide a link to the Creative Commons licence, and indicate if changes were made. The images or other third party material in this article are included in the article's Creative Commons licence, unless indicated otherwise in a credit line to the material. If material is not included in the article's Creative Commons licence and your intended use is not permitted by statutory regulation or exceeds the permitted use, you will need to obtain permission directly from the copyright holder. To view a copy of this licence, visit http://creativecommons.org/licenses/by/4.0/.

\section{References}

Abade L, Cusack J, Moll RJ, Strampelli P, Dickman AJ, Macdonald DW, Montgomery, RA (2018) Spatial variation in leopard (Panthera pardus) site use across a gradient of anthropogenic pressure in Tanzania's Ruaha landscape. PLoS ONE 13(10):e0204370

Acharya KP, Paudel PK, Jnawali SR, Neupane PR, Köhl M (2017) Can forest fragmentation and configuration work as indicators of human-wildlife conflict? Evidences from human death and injury by wildlife attacks in Nepal. Ecol Ind 80:74-83

Askerov E, Talibov T, Manvelyan K, Zazanashvili N, Malkhasyan A, Fatullayev P, Heidelberg A (2015) SouthEastern Lesser Caucasus: the most important landscape for conserving the Leopard (Panthera pardus) in the Caucasus region (Mammalia: Felidae). Zool Middle East 61(2):95-101

Athreya V, Srivathsa A, Puri M, Karanth KK, Kumar NS, Karanth KU (2015) Spotted in the news: using media reports to examine leopard distribution, depredation, and management practices outside protected areas in southern India. PLoS ONE 10(11):e0142647

Atkins JL, Long RA, Pansu J, Daskin JH, Potter AB, Stalmans ME, Tarnita CE, Pringle RM (2019) Cascading impacts of large-carnivore extirpation in an African ecosystem. Science 364(6436): 173-177

Aylward CM, Murdoch JD, Donovan TM, Kilpatrick CW, Bernier C, Katz J (2018) Estimating distribution and connectivity of recolonizing American marten in the northeastern United States using expert elicitation techniques. Anim Conserv 21(6):483-495

Balme G, Hunter L, Slotow R (2007) Feeding habitat selection by hunting leopards Panthera pardus in a woodland savanna: prey catchability versus abundance. Anim Behav 74(3):589-598

Beier P (2019) A rule of thumb for widths of conservation corridors. Conserv Biol 33(4):976-978

Beier P, Majka DR, Spencer WD (2008) Forks in the road: Choices in procedures for designing wildland linkages. Conserv Biol 22(4):836-851

Benitez-Lopez A, Alkemade R, Schipper AM, Ingram DJ, Verweij PA, Eikelboom JAJ, Huijbregts MAJ (2017) The impact of hunting on tropical mammal and bird populations. Science 356:180-183

Bleicher SS (2017) The landscape of fear conceptual framework: definition and review of current applications and misuses. PeerJ 5:e3772

Bleyhl B, Baumann M, Griffiths P, Heidelberg A, Manvelyan K, Radeloff VC, Zazanashvili N, Kuemmerle T (2017) Assessing landscape connectivity for large mammals in the Caucasus using Landsat 8 seasonal image composites. Remote Sens Environ 193:193-203

Broekhuis F, Cushman SA, Elliot NB (2017) Identification of human-carnivore conflict hotspots to prioritize mitigation efforts. Ecol Evol 7(24):10630-10639

Burnham KP, Anderson DR (2002) Model selection and multimodel inference. Springer, New York, NY

Carvalho EAR, Zarco-González MM, Monroy-Vilchis O, Morato RG (2015) Modeling the risk of livestock 
depredation by jaguar along the Transamazon highway. $\mathrm{Br}$ Basic Appl Ecol 16(5):413-419

Chambert T, Miller DAW, Nichols JD (2015) Modeling false positive detections in species occurrence data under different study designs. Ecology 96(2):332-339

Chapron G, Kaczensky P, Linnell JDC, von Arx M, Huber D, Andrén H, López-Bao JV, Adamec M, Álvares F, Anders O, Balčiauskas L, Balys V, Bedő P, Bego F, Blanco JC, Breitenmoser U, Brøset H, Bufk L, Bunikyte R, Ciucci P, Dutsov A, Engleder T, Fuxjäger C, Groff C, Holmala K, Hoxha B, Iliopoulos Y, Ionescu O, Jeremić J, Jerina K, Kluth G, Knauer F, Kojola I, Kos I, Krofel M, Kubala J, Kunovac S, Kusak J, Kutal M, Liberg O, Majić A, Männil P, Manz R, Marboutin E, Marucco F, Melovski D, Mersini K, Mertzanis Y, Mysłajek RW, Nowak S, Odden J, Ozolins J, Palomero G, Paunović M, Persson J, Potočnik H, Quenette PY, Rauer G, Reinhardt I, Rigg R, Ryser A, Salvatori V, Skrbinšek T, Stojanov A, Swenson JE, Szemethy L, Trajçe A, Tsingarska-Sedefchev E, Váňa M, Veeroja R, Wabakken P, Wölfl M, Wölfl S, Zimmermann F, Zlatanova D, Boitani L (2014) Recovery of large carnivores in Europe's modern human-dominated landscapes. Science 346(6216):1517-1519

Chetkiewicz C-LB, Clair CCS, Boyce MS (2006) Corridors for conservation: integrating pattern and process. Annu Rev Ecol Evol Syst 37(1):317-342

Ciuti S, Northrup JM, Muhly TB, Simi S, Musiani M, Pitt JA, Boyce MS (2012) Effects of humans on behaviour of wildlife exceed those of natural predators in a landscape of fear. PLoS ONE 7(11):e50611

Crooks KR, Burdett CL, Theobald DM, Rondinini C, Boitani L (2011) Global patterns of fragmentation and connectivity of mammalian carnivore habitat. Philos Trans Royal Soc B: Biol Sci 366(1578):2642-2651

Cushman SA, Chase M, Griffin C. (2010). Mapping landscape resistance to identify corridors and barriers for elephant movement in southern Africa. In: Cushman S. A. andHuettmann F. (eds), Spatial Complexity, Informatics, and Wildlife Conservation. Springer Japan: Tokyo, pp. 349-367

Cushman SA, Elliot NB, Bauer D, Kesch K, Baha-El-Din L, Bothwell H, Flyman M, Mtare G, Macdonald DW, Loveridge AJ (2018) Prioritizing core areas, corridors and conflict hotspots for lion conservation in southern Africa. PLoS ONE 13(7):e0196213

Di Marco M, Boitani L, Mallon D, Hoffmann M, Iacucci A, Meijaard E, Visconti P, Schipper J, Rondinini C (2014) A retrospective evaluation of the global decline of carnivores and ungulates. Conserv Biol 28(4):1109-1118

Di Minin E, Slotow R, Hunter LTB, Montesino Pouzols F, Toivonen T, Verburg PH, Leader-Williams N, Petracca L, Moilanen A (2016) Global priorities for national carnivore conservation under land use change. Sci Rep 6:23814

Dorresteijn I, Schultner J, Nimmo DG, Fischer J, Hanspach J, Kuemmerle T, Kehoe L, Ritchie EG (2015) Incorporating anthropogenic effects into trophic ecology: predator-prey interactions in a human-dominated landscape. Proc Royal Soc B Biol Sci 282(1814):20151602
Dutta T, Sharma S, McRae BH, Roy PS, DeFries R (2016) Connecting the dots: mapping habitat connectivity for tigers in central India. Reg Environ Change 16(1):53-67

Farhadinia MS, Johnson PJ, Macdonald DW, Hunter LTB (2018) Anchoring and adjusting amidst humans: ranging behavior of persian leopards along the Iran-Turkmenistan borderland. PLoS ONE 13(5):e0196602

Ferreira AS, Peres CA, Bogoni JA, Cassano CR (2018) Use of agroecosystem matrix habitats by mammalian carnivores (Carnivora): a global-scale analysis. Mamm Rev 48(4):312-327

Festa-Bianchet M (2018) Learning to migrate. Science 361(6406):972-973

Fiske IJ, Chandler RB (2011) unmarked: an R package for fitting hierarchical models of wildlife occurrence and abundance. J Stat Softw 43(10):1-23

Gehr B, Hofer EJ, Muff S, Ryser A, Vimercati E, Vogt K, Keller LF (2017) A landscape of coexistence for a large predator in a human dominated landscape. Oikos 126(10):1389-1399

Ghoddousi A, Soofi M, Kh Hamidi A, Lumetsberger T, Egli L, Khorozyan I, H Kiabi B, Waltert M (2016) Assessing the role of livestock in big cat prey choice using spatiotemporal availability patterns. PLoS ONE 11(4):e0153439

Ghoshal A, Bhatnagar YV, Pandav B, Sharma K, Mishra C, Raghunath R, Suryawanshi KR (2017). Assessing changes in distribution of the Endangered snow leopard Panthera uncia and its wild prey over 2 decades in the Indian Himalaya through interview-based occupancy surveys. Oryx 1-13

Ghoddousi A, Egli L, Soofi M, Khorozyan I, Waltert M (2017) After sanctions: the urge to upgrade and integrate conservation in Iran. Front Ecol Environ 15(1):9-10

Goswami VR, Vasudev D (2017) Triage of conservation needs: the juxtaposition of conflict mitigation and connectivity considerations in heterogeneous, human-dominated landscapes. Front Ecol Evol 4(144):1-7

Hebblewhite M, Merrill EH, McDonald TL (2005) Spatial decomposition of predation risk using resource selection functions: an example in a wolf-elk predator-prey system. Oikos 111(1):101-111

Jędrzejewski W, Carreño R, Sánchez-Mercado A, Schimdt K, Abarca M, Robinson HS, Boede EO, Hoogesteijn R, Viloria AL, Cerda H, Velasquez G, Zambrano-Martinez S (2017) Human-jaguar conflicts and the relative importance of retaliatory killing and hunting for jaguar (Panthera onca) populations in Venezuela. Biol Cons 209:524-532

Johnston A, Fink D, Hochachka WM, Kelling S, Isaac N (2018) Estimates of observer expertise improve species distributions from citizen science data. Methods Ecol Evol 9(1):88-97

Keeley ATH, Beier P, Gagnon JW (2016) Estimating landscape resistance from habitat suitability: effects of data source and nonlinearities. Landscape Ecol 31(9):2151-2162

Khorozyan I, Ghoddousi A, Soofi M, Waltert M (2015) Big cats kill more livestock when wild prey reaches a minimum threshold. Biol Cons 192:268-275

Kiabi BH, Dareshouri BF, Ghaemi RA, Jahanshahi M (2002) Population status of the Persian Leopard (Panthera pardus saxicolor Pocock, 1927) in Iran. Zool Middle East 26:41-47 
Krafte Holland K, Larson LR, Powell RB (2018) Characterizing conflict between humans and big cats Panthera spp: A systematic review of research trends and management opportunities. PLoS ONE 13(9):e0203877

Kramer-Schadt S, Kaiser ST, Frank K, Wiegand T (2011) Analyzing the effect of stepping stones on target patch colonisation in structured landscapes for Eurasian lynx. Landscape Ecol 26(4):501-513

Kshettry A, Vaidyanathan S, Athreya V (2017) Leopard in a teacup: a study of leopard habitat-use and human-leopard interactions in north-eastern India. PLoS ONE 12(5): 0177013

LaPoint S, Gallery P, Wikelski M, Kays R (2013) Animal behavior, cost-based corridor models, and real corridors. Landscape Ecol 28(8):1615-1630

Lennox RJ, Gallagher AJ, Ritchie EG, Cooke SJ (2018) Evaluating the efficacy of predator removal in a conflict-prone world. Biol Cons 224:277-289

Little SJ, Harcourt RG, Clevenger AP (2002) Do wildlife passages act as prey-traps? Biol Cons 107(2):135-145

Lumetsberger T, Ghoddousi A, Appel A, Khorozyan I, Waltert M, Kiffner C (2017) Re-evaluating models for estimating prey consumption by leopards. J Zool 302(3):201-210

MacKenzie DI, Nichols JD (2004) Occupancy as a surrogate for abundance estimation. Anim Biodiv Conserv 27(1):461-467

MacKenzie DI, Nichols JD, Royle JA, Pollock K, Bailey LL, Hines JE. (2017). Occupancy estimation and modeling 2nd edition; inferring patterns and dynamics of species occurrence. Academic Press

Martinez-Marti C, Jimenez-Franco MV, Royle JA, Palazon JA, Calvo JF (2016) Integrating occurrence and detectability patterns based on interview data: a case study for threatened mammals in Equatorial Guinea. Sci Rep 6:33838

McGarigal K, Cushman SA, Ene E. (2012). FRAGSTATS v4: Spatial pattern analysis program for categorical and continuous maps. University of Massachusetts, Amherst. https://www.umass.edu/landeco/research/fragstats/ fragstats.html

McRae BH, Dickson BG, Keitt TH, Shah VB (2008) Using circuit theory to model connectivity in ecology, evolution, and conservation. Ecology 89(10):2712-2724

Michalski F, Boulhosa RLP, Faria A, Peres CA (2006) Humanwildlife conflicts in a fragmented Amazonian forest landscape: determinants of large felid depredation on livestock. Anim Conserv 9(2):179-188

Miller DA, Nichols JD, McClintock BT, Campbell Grant EH, Bailey LL, Weir LA (2011) Improving occupancy estimation when two types of observational error occur: nondetection and species misidentification. Ecology 92(7):1422-1428

Miller JRB (2015) Mapping attack hotspots to mitigate humancarnivore conflict: approaches and applications of spatial predation risk modeling. Biodivers Conserv 24(12):2887-2911

Momeni Dehghani I, Salman Mahiny A, Alizadeh Shabani A, Karami M (2013) Efficiency of current reserve network in Golestan Province (Iran) for the protection of hoofed ungulates. Biodiversity 14(3):162-168
Northrup JM, Stenhouse GB, Boyce MS (2012) Agricultural lands as ecological traps for grizzly bears. Anim Conserv 15(4):369-377

Odden M, Athreya V, Rattan S, Linnell JDC (2014) Adaptable neighbours: movement patterns of GPS-collared leopards in human dominated landscapes in India. PLoS ONE 9(11):e112044

Petracca LS, Frair JL, Cohen JB, Calderón AP, Carazo-Salazar J, Castañeda F, Corrales-Gutiérrez D, Foster RJ, Harmsen B, Hernández-Potosme S, Herrera L, Olmos M, Pereira S, Robinson HS, Robinson N, Salom-Pérez R, Urbina Y, Zeller KA, Quigley H (2018) Robust inference on largescale species habitat use with interview data: the status of jaguars outside protected areas in Central America. J Appl Ecol 55(2):723-734

Petracca LS, Hernández-Potosme S, Obando-Sampson L, Salom-Pérez R, Quigley H, Robinson HS (2014) Agricultural encroachment and lack of enforcement threaten connectivity of range-wide jaguar (Panthera onca) corridor. J Nat Conserv 22(5):436-444

Pillay R, Miller DAW, Hines JE, Joshi AA, Madhusudan MD, Wintle B (2014) Accounting for false positives improves estimates of occupancy from key informant interviews. Divers Distrib 20(2):223-235

Riggio J, Caro T (2017) Structural connectivity at a national scale: wildlife corridors in Tanzania. PLoS ONE 12(11):e0187407

Ripple WJ, Estes JA, Beschta RL, Wilmers CC, Ritchie EG, Hebblewhite M, Berger J, Elmhagen B, Letnic M, Nelson MP, Schmitz OJ, Smith DW, Wallach AD, Wirsing AJ (2014) Status and ecological effects of the world's largest carnivores. Science 343(6167): 1241484

Rödder D, Nekum S, Cord AF, Engler JO (2016) Coupling satellite data with species distribution and connectivity models as a tool for environmental management and planning in matrix-sensitive species. Environ Manage 58(1):130-143

Romero-Muñoz A, Torres R, Noss AJ, Giordano AJ, Quiroga V, Thompson JJ, Baumann M, Altrichter M, McBride Jr R, Velilla M, Arispe R, Kuemmerle T (2019) Habitat loss and overhunting synergistically drive the extirpation of jaguars from the Gran Chaco. Divers Distrib 25(2):176-190

Rostro-García S, Tharchen L, Abade L, Astaras C, Cushman SA, Macdonald DW (2016) Scale dependence of felid predation risk: identifying predictors of livestock kills by tiger and leopard in Bhutan. Landscape Ecol 31(6): 1277-1298

Sanderson EW, Redford KH, Vedder A, Coppolillo PB, Ward SE (2002) A conceptual model for conservation planning based on landscape species requirements. Landsc Urban Plan 58(1):41-56

Scharf AK, Belant JL, Beyer DE Jr, Wikelski M, Safi K (2018) Habitat suitability does not capture the essence of animaldefined corridors. Mov Ecol 6:18

Steger C, Butt B, Hooten MB, du Toit J (2017) Safari Science: assessing the reliability of citizen science data for wildlife surveys. J Appl Ecol 54(6):2053-2062

Stevenson-Holt CD, Watts K, Bellamy CC, Nevin OT, Ramsey AD (2014) Defining landscape resistance values in leastcost connectivity models for the invasive grey squirrel: a 
comparison of approaches using expert-opinion and habitat suitability modelling. PLoS ONE 9(11):e112119

Taubmann J, Sharma K, Uulu KZ, Hines JE, Mishra C (2015) Status assessment of the Endangered snow leopard Panthera uncia and other large mammals in the Kyrgyz Alay, using community knowledge corrected for imperfect detection. Oryx 50(02):220-230

Tilman D, Clark M, Williams DR, Kimmel K, Polasky S, Packer C (2017) Future threats to biodiversity and pathways to their prevention. Nature 546(7656):73-81

Tischendorf L, Fahrig L (2000) On the usage and measurement of landscape connectivity. Oikos 90(1):7-19

Treves A, Karanth KU (2003) Human-carnivore conflict and perspectives on carnivore management worldwide. Conserv Biol 17(6):1491-1499

van Eeden LM, Crowther MS, Dickman CR, Macdonald DW, Ripple WJ, Ritchie EG, Newsome TM (2018) Managing conflict between large carnivores and livestock. Conserv Biol 32(1):26-34

Vanbianchi C, Gaines WL, Murphy MA, Hodges KE (2018) Navigating fragmented landscapes: canada lynx brave poor quality habitats while traveling. Ecol Evol 8(22):11293-11308
Vasudev D, Fletcher RJ, Goswami VR, Krishnadas M (2015) From dispersal constraints to landscape connectivity: lessons from species distribution modeling. Ecography 38(10):967-978

Vogt P, Riitters K (2017) GuidosToolbox: universal digital image object analysis. Europ J Remote Sens 50(1):352-361

Wolf C, Ripple WJ (2017) Range contractions of the world's large carnivores. Royal Soc Open Sci 4(7):170052

Zeller KA, Nijhawan S, Salom-Pérez R, Potosme SH, Hines JE (2011) Integrating occupancy modeling and interview data for corridor identification: a case study for jaguars in Nicaragua. Biol Cons 144(2):892-901

Zeller KA, McGarigal K, Whiteley AR (2012) Estimating landscape resistance to movement: a review. Landsc Ecol 27(6):777-797

Publisher's Note Springer Nature remains neutral with regard to jurisdictional claims in published maps and institutional affiliations. 